\title{
LAW AND JUSTICE OUTSIDE THE CBD
}

\section{Chief Justice Robert French*}

Rural and regional Australia frames much of our national history and cultural heritage and therefore of our identity as a people. The oldest and most pervasive part of that history and heritage is found in the intricate and beautiful legends of the Dreamtime which have mapped and named Australian landscapes for tens of thousands of years. Those legends find visual, aural and kinetic expression in the art, songs and dances of Aboriginal people living and dead, which we and the world have only really begun to appreciate in the last half century. The rise of that appreciation and the affirmation by Aboriginal people of their cultural heritage perhaps mitigates the darker aspect of the consequences of colonisation reflected in the first verse of Judith Wright's poem, Bora Ring:

The song is gone, the dance is secret with the dancers in the earth, the ritual useless, and the tribal story lost in an alien tale. ${ }^{1}$

Much of our art and literature has been and is about the people and places of rural and regional Australia. Many of my generation at school, when not memorising the dotted lines showing the paths followed by early explorers, were reading poets, including Judith Wright, and story-tellers and novelists and looking at paintings which derived their inspiration and subject matter from rural Australia. One of Australia's great novelists of the first half of the twentieth century was Ethel Richardson, who wrote under the pseudonym, Henry Handel Richardson. As a schoolboy I studied her trilogy, The Fortunes of Richard Mahony. The title of the first part, Australia Felix, was the term used by one of those dotted-line explorers, Major Thomas Mitchell, in 1836 to describe the fertile country of western Victoria. It was set in Ballarat at the time of the gold rushes. A more recent example from my own state is Tim Winton's Breath, which is set in a fictitious South West logging town which

\footnotetext{
${ }^{*}$ Chief Justice of the High Court of Australia.

${ }^{1}$ Judith Wright, A Human Pattern: Selected Poems (ETT Imprint, 1996).
} 
he calls 'Sawyer', but which many people believe to be based on Denmark, about 50 kilometres west of Albany.

The prominence in our art and literature, and indeed in our political discourse, of regional and rural themes is not surprising. Australia is a country of between 21 and 22 million people, who occupy a land area of 7.7 million square kilometres, most of which is outside the CBDs of our capital cities. By way of illustration of the size of our country, a few years ago, as a Federal Court Judge, I made a consent determination of native title in the desert country of Western Australia. The area of the determination was the size of Belgium. Only a few hundred people occupied the land - it was east of the most eastward extension of pastoral activity in Western Australia. The only respondents to the application for native title were the State government and one or two mining companies with exploration interests.

In spite of Australia's vast land area we are one of the most urbanised countries in the world. More than two thirds of our population, as measured by the 2006 Census, live in major cities. The remainder live in regional and remote areas. The urban concentration in New South Wales, Victoria, South Australia and Western Australia is in excess of 70 per cent of the total population. As Australia's population grows its concentration in the capital cities is expected to increase relative to regional and rural areas. ${ }^{2}$ On the other hand, at the time of the last census, more than two thirds of Indigenous people in Australia lived in inner regional, outer regional, remote and very remote areas.

Although less than a third of all Australians live outside our capital cities, their communities contribute in a major way to our national economy, particularly in the agricultural and mining sectors. Agriculture accounts for about 3 per cent of our gross domestic product, and 3.5 per cent of total national employment. Two thirds of production is exported and represents 20 per cent of our merchandise exports. ${ }^{3}$ Mining contributes about 8 per cent to gross domestic product, although that fluctuates. It is nevertheless predominantly a regional and rural activity which at the larger end of the sector generates its own towns and communities and issues relevant to this conference.

\footnotetext{
2 Brian Pink, 'Australian Social Trends 2008' (Australian Bureau of Statistics, July 2008) 12 $<$ http://www.ausstats.abs.gov.au/ausstats/subscriber.nsf/0/DE5DE30C9CF6E5E3CA25748E0 0126A25/\$File/41020_2008.pdf >.

${ }^{3}$ Australia 2020 Summit, 'The Future of Rural and Regional Australia' (Background Paper, Australian Government, April 2008) $4<$ http://www.australia2020.gov.au/topics/docs/ rural.pdf $>$.
} 
Rural, regional and remote Australia, and its people, are important to us all in a variety of ways. They are embedded in our history, our culture and our national identity. They are also important to our economy. They are entitled to the same benefits of living in Australia - so far as practicable (and there is the rub) - as those who live in cities. This entitlement is never higher than in relation to the rule of law, the administration of justice and the provision of legal services.

I have been fortunate in my legal career to have seen some of the different faces of rural Australia, to appreciate its diversity, and with that to appreciate the dangers of over-generalising about issues such as law and justice in this context. Rural, regional and remote Australia is not homogeneous. The three designations give us the clue to that. One of my personal experiences of rural Australia arose from operating a legal practice in the 1970s in Kojonup, a farming town about 250 kilometres south of Perth. The law firm which I established with three friends in 1975 in Perth opened an office in that town, which we visited once a week or fortnight. It was, at the time, a relatively affluent farming area and our primary client was the local accountant who referred many of his clients to us. One of us would make the drive from Perth to Kojonup to meet with clients, take instructions and provide advice. The range of work was indicative of that community and no doubt a number of others like it. There was a lot of conveyancing, will-making, farm sales and succession planning involved. Death duties were in force at the time and many farmers wanted to arrange their affairs by selling the farm to their children and forgiving the debt by instalments so as to minimise the size of their dutiable estates. Succession planning in the small farming sector is still important even without death duties. I was interested to see that the Law Institute of Victoria operates a Rural Law Online website. It provides Feature Issue Forums. One of those was a forum on Farm Succession Planning. Here the law engages with a very real social issue. It was reported on the site that:

... the Forum postings highlighted the emotional trauma, financial loss and the often irrevocable damage sustained to family relationships, which can occur where planned succession is not an integral part of managing the farming business. ${ }^{4}$

Problems may also arise where, under a planned succession, a farming couple dispose of the farm to their children, but then cannot let go of the operation when the time comes.

4 Rural Law Online, 'Farm Succession Planning' (Forum Report, December 2005) 10 $<\mathrm{http}$ ://www.rurallaw.org.au/resources/FarmSuccessionPlanningForumReport.pdf $>$. 
The services we offered in Kojonup were multi-faceted, as they had to be when serving clients in a small country town. Occasionally, one of our farming clients would get into trouble with the law, particularly the traffic police. We would provide representation in the Kojonup Court of Petty Sessions. For those from divided professions, I should point out that the legal profession in Western Australia is not divided, although it has a voluntary independent Bar. So, as Barristers and Solicitors, we did much of our own advocacy work in all courts. There were Indigenous families living in the community. We took instructions to represent them from time to time. One particular family was a source of quite a lot of work - mainly, as I recall, legally aided. I represented one of its members on a charge of manslaughter following a fatal accident involving a semi-trailer which he was driving after having delivered some sheep to a farm. It was a tragic accident due to somebody else's stupidity. He was not really at fault and was properly acquitted. After I retired from the firm in 1983, and went to the Bar, the firm sold the Kojonup practice to one of its employees. I frequently drive through Kojonup on the way to Denmark and note that our successor firm's sign is still up there.

I had different experiences as part of the Law Society of Western Australia's flying lawyer service in the 1970s, visiting mining towns like Tom Price and providing on-the-spot advice for mining workers and their families. A significant amount of the advice at the time related to family breakdowns. For a non-working spouse or partner these towns could be very tedious indeed, although there were endeavours to provide opportunities for developing networks and associations within that community. No doubt things have improved considerably since that time.

My most extensive and intensive interaction with rural, regional and remote Australia was as President of the National Native Title Tribunal, an office which I held from 1994 to 1998 . That brought home to me, like no other experience, the extraordinary variation to be found in the Australia that lies outside the major cities. That variation encompasses large urban concentrations like Townsville and Toowoomba in Queensland, regional ports and tourist centres, the mining towns of North-West Australia, tiny Aboriginal settlements and the array of small country towns, like Kojonup, servicing the agricultural sector right across the country. That variation which I experienced personally makes a mockery of attempts to stereotype the attitudes and problems of regional Australia.

Having said all that, people living in regional Australia face disadvantages and they face difficulties in trying to overcome or mitigate them. The obvious ones are the relatively small populations of many country towns and their 
distance, and that of regional centres, from each other and from the major cities. Those factors, which have always been a feature of country Australia, are manifested in the lack of availability and high cost of facilities, goods and services, both public and private including health, housing, education, policing, law and justice. There are other large issues looming which interact with these constants. One is declining rainfall and extended droughts, which have given rise to issues about allocation of water rights, particularly in the Murray-Darling Basin, and restrictions on the clearing of native vegetation. The tensions generated by those issues between rural land uses and governments have manifested themselves in the last 12 months in litigation in the High Court. There have been challenges to the implementation by the State government of New South Wales of reduced water entitlements for irrigators $^{5}$ and restrictions imposed by the government of that State on the clearing of native vegetation. ${ }^{6}$ There is also pending water-rights litigation between South Australia and Victoria. South Australia is challenging the validity of limits placed by Victorian law on the trading of water licences across the Victorian-South Australian border. Among other current issues facing rural and regional areas are intergenerational change, changing patterns of land ownership, shortages of services and skills, and access to physical and electronic infrastructure. ${ }^{7}$

Changing patterns of land ownership are reflected in the amalgamation of properties in the interests of economic efficiency. As a result, some families have left the industry. The small towns that serviced them have suffered population declines as a result. The Australian Bureau of Statistics said in a report, published in 2003, quoted on the Forum site:

For some farming families, farm income has reduced due to declining profit margins, and can be highly variable, requiring some farmers and family members to obtain off-farm employment to supplement and stabilise the family income. Stress, overwork and reduced time for family and community activities can affect the wellbeing of farmers and their families. ${ }^{8}$

This conference is concerned about a subset of this large suite of issues. That subset falls under the broad rubric of access to and delivery of justice and legal services. Although it is a subset of rural, regional and remote country

${ }^{5}$ ICM Agriculture Pty Ltd v The Commonwealth (2009) 240 CLR 140; Arnold v Minister Administering the Water Management Act 2000 (2010) 240 CLR 242.

${ }^{6}$ Spencer v Commonwealth of Australia (2010) 269 ALR 253.

${ }^{7}$ Australia 2020 Summit, above n 3, 5-8.

${ }^{8}$ Dennis Trewin, 'Australian Social Trends 2003' (Australian Bureau of Statistics, June 2003) $45<\mathrm{http}: / /$ www.ausstats.abs.gov.au/ausstats/subscriber.nsf/0/70AC02A724F4033 FCA256D3A0006B054/\$File/41020_2003.pdf>. 
issues, it raises for consideration a range of diverse and complex topics. They intersect with broader social issues, some of which may affect communities as a whole, some of which may be particularly acute among Indigenous people, and some of which may also affect Indigenous and non-Indigenous relations within those communities. A number of these matters are reflected in this conference program.

The challenge of providing access to justice equitably is one which faces the whole of the Australian community. It has been much considered over many years and has been productive of many government and non-governmentsector inquiries and reports.

In 1993, Professor Ronald Sackville, later Justice Sackville of the Federal Court of Australia, chaired a committee called the 'Access to Justice Advisory Committee', which had been established by the Attorney-General, Michael Lavarch, and the Minister for Justice, Duncan Kerr. The Committee reported in 1994. In making recommendations for a national strategy for access to justice the Committee identified three objectives:

1. Equality of access to legal services;

2. National equity;

3. Equality before the law.

Under the heading 'National Equity' the Committee implicitly recognised rural disadvantage. It stated:

All Australians, regardless of their place of residence, should enjoy, as nearly as possible, equal access to legal services and to legal services markets that function competitively. To the extent that there are variations in access among States or regions, they should have to be justified by reason of special, identifiable circumstances. Uniformity is not necessarily a goal to be pursued in itself. But the Australian Government, in particular, should prevent people being denied access to legal services simply because of where they happen to live. ${ }^{9}$

Moving forward past many 'Access to Justice' reports, including two prepared by the Senate Legal and Constitutional Affairs Committee in 1998 and 2001, the problem is still engaging us. In 2009, the Attorney-General's Department set up an Access to Justice Taskforce which, in September 2009,

\footnotetext{
${ }^{9}$ Access to Justice Advisory Committee, Access to Justice: An Action Plan (Canberra: AGPS, 1994) xxx.
} 
published a report and a document entitled A Strategic Framework for Access to Justice in the Federal Civil Justice System: A Guide for Future Action. ${ }^{10}$ Key conclusions from the Taskforce's examination of demand for dispute resolution services were:

1. Information failure is a significant issue because people do not understand legal events and what to do or where to seek assistance;

2. People do not generally seek to use courts or formal justice mechanisms as a means of obtaining assistance in relation to legal issues;

3. Legal events are experienced across all parts of society, although not randomly.

The range of mechanisms for dispute resolution were identified as including:

- Information, advice and support;

- Internal complaint mechanisms;

- External dispute resolution and ombudsmen;

- Administrative law remedies;

- Family dispute resolution services;

- Alternative dispute resolution, including mediation, negotiation and arbitration;

- Courts and tribunals.

Many of these have application to rural and regional communities. Some of them are readily adapted to online delivery. One interesting innovation in the Singapore courts, which might have some application in Australia, is the concept of online mediation which involves setting up a kind of chat-room for parties to litigation and an online mediator. The idea has, I think, some potential for wider application.

\footnotetext{
${ }^{10}$ Available at $<$ http://www.ag.gov.au/a2j> .
} 
Yesterday in Sydney, the Attorney-General convened a Roundtable on access to justice arising out of the Taskforce Report and Recommendations. Heads of jurisdiction, senior officials and representatives of the profession were in attendance. There is a clear, ongoing public, professional and governmental interest in this topic. At a broad societal level it will be with us for a long time. In my opinion, however, the problems it raises in relation to rural, regional and remote communities are more acute than those experienced in major urban centres and require a specific type of attention.

Since the Sackville Committee published its Report in 1994, there has been a plethora of reports, surveys and studies relating to law and justice issues in rural and regional Australia. They have covered such topics as:

1. The history of courts, judges, lawyers and crime in rural Australia. (I mention these specifically because I do not think one gets a full picture of law and justice issues simply by looking at snapshots frozen in time. In rural, regional and remote communities they are likely to be embedded in social issues and local histories.);

2. Dispute resolution, therapeutic jurisprudence and restorative justice;

3. The availability of legal services;

4. The recruitment and retention of lawyers to practise in rural and regional areas;

5. Legal aid and pro bono legal services;

6. Human rights.

Of all of those topics, three have perhaps together generated more consideration and publication than others. They are the availability of legal services, the recruitment and retention of lawyers, and the provision of legal aid and pro bono legal services.

Three weeks ago I received from the Law and Justice Foundation of New South Wales a report largely funded by the Australian Government AttorneyGeneral's Department Social Inclusion Division. The report was entitled 'Recruitment and retention of lawyers in regional, rural and remote New 
South Wales'. ${ }^{11}$ The authors, two of whom are speaking at one of the sessions in this conference, reported that public legal services for disadvantaged people in New South Wales had faced difficulties in recruiting and retaining solicitors in regional, rural and remote areas. Difficulties were also experienced in attracting sufficient private solicitors to undertake legal-aid work. This observation took its place within what the authors described as '... a broader context of the social and economic decline experienced by rural Australia'. ${ }^{12}$

A general conclusion of the report, which I think is of importance, and which accords with my own experience, is that different rural, regional and remote areas have different characteristics. Some areas have recruitment and retention difficulties, which others do not. Australia cannot simply be divided into the city and the country and the assumption made that there is a common set of law and justice issues applicable to each rural community. There is much variability between rural, regional and remote centres based not only on population, but also location, including proximity to major centres.

The major findings of the New South Wales study indicated, not surprisingly, that the ratio of residents to locally based lawyers, both public and private, increased with remoteness. A significant number of local government areas in New South Wales do not have a single solicitor, private or public, based in the area. The populations of the majority of areas were in decline. This suggests, as the authors inferred, that, in these remote and less populated parts of the country, there may not be enough legal work to sustain a fulltime resident solicitor. That, of course, does not mean that the supply of legal services to such communities is impossible or impracticable. The provision of online and visiting services may be two ways of dealing with that problem, dependent upon the particular circumstances of the community.

There were disparities in age, experience and in the remuneration of solicitors across public legal assistance services in different parts of New South Wales. Those disparities contributed to the movement of solicitors between services and from more remote areas to inner regional areas and to urban areas. The authors observed sensibly that:

\footnotetext{
${ }^{11}$ Suzie Forell, Michael Cain and Abigail Gray, 'Recruitment and Retention of Lawyers in Regional, Rural and Remote New South Wales' (Report, Law and Justice Foundation of New South Wales, September 2010) <http://www.lawfoundation.net.au/ljf/site/articleIDs/ 53FAC0137BED4F38CA2577BA0024256B/\$file/Recruitment_and_retention_of_lawyers_in RRR_NSW_web.pdf $>$.

${ }^{12}$ Ibid vii.
} 
$\ldots$ given these realities individual solutions to recruitment and retention difficulties need to be area specific, problem specific and, in some cases, position specific. ${ }^{13}$

In a report published in July last year, the Law Council of Australia and the Law Institute of Victoria released the results of a survey into recruitment and retention problems of law firms and community legal centres in rural, regional and remote areas. ${ }^{14}$ The report was based on a nation-wide survey of legal practitioners in those areas. Major findings included the following:

1. Forty-three per cent of principals surveyed indicated that their practice did not have enough lawyers to service their client base;

2. Forty-two per cent of the legal practitioners who responded to the survey did not intend to practise law in five years time. It was necessary to find practitioners to fill those gaps; otherwise many legal businesses would close for want of successors;

3. The principals of country firms were extremely worried about the future of the profession in their regions. Seventy-one per cent of them cited succession planning as their biggest concern. This was followed by concerns about attracting additional lawyers to the firm and about attracting lawyers to replace departures;

4. Many younger lawyers were intending to leave their work in rural, regional or remote areas to seek better remuneration or to work in the city. Thirty per cent in the 30-39 age range indicated that they only intended to practise in their area for less than two years. Remuneration was extremely important for this group, with a quarter of them indicating that they would leave the country for better pay;

5. Just over half of country practitioners who responded to the survey indicated that their firm accepted legally-aided matters. The majority dealt with more than 30 such cases per year. This supports an earlier study which found that law firms in regional and remote areas provide larger quantities of legal-aid work than their city counterparts;

\footnotetext{
${ }^{13}$ Ibid ix.

${ }^{14}$ Law Council of Australia and Law Institute of Victoria, 'Report into the Rural Regional and Remote Areas Lawyers Survey' (July 2009) <http://www.lawcouncil.asn.au/shadomx/ apps/fms/fmsdownload.cfm?file_uuid=58075666-1E4F-17FA-D22C-

92C2CC13DA7C\&siteName $=$ lca $>$.
} 
6. More than 64 per cent of the respondents indicated that their firms undertook pro bono work.

While the results of the survey did not appear to distinguish between different centres within rural Australia, its findings were indicative of a significant problem. A number of initiatives were suggested in a working draft paper published by the Law Council of Australia in September 2009. ${ }^{15}$ They included collaborative action by elements of the legal profession, the provision of incentives by government, and initiatives by employers, legal firms and organisations. Among the latter initiatives were:

- Provision and promotion of life-style benefits unavailable in metropolitan areas;

- Increasing social and professional networking opportunities and family support;

- Collaboration with law societies and other legal assistance stakeholders in facilitating provision of information to law students and graduates about vacancies;

- The placement of law students and practitioners in rural, regional and remote areas;

- Visiting services by legal practitioners;

- The provision of continuing professional development and professional support;

- Increasing use of technology to reduce isolation and travelling time for practitioners.

There are of course particularly difficult issues which face rural and regional and remote communities in relation to criminal justice and specifically in the area of juvenile offending, domestic violence and child abuse. They are illustrated by problems facing juveniles who have been the victims of child abuse or neglect and are consequently at greater risk of becoming criminal offenders. The notion of a vicious cycle of abuse and offending is not a new

${ }^{15}$ Law Council of Australia, 'Recruitment and Retention of Legal Practitioners to Rural, Regional and Remote Areas Strategy: Discussion Paper', (Working Draft, September 2009) $17<$ http://www.lawcouncil.asn.au/shadomx/apps/fms/fmsdownload.cfm?file_uuid=6C3E C57C-1E4F-17FA-D225-445270E49D9A\&siteName=lca $>$. 
one. It is exacerbated in rural, regional and remote areas. There are also ancillary issues involving offenders from small communities where many, if not most, people know each other. This can sometimes affect the availability of bail, of community-based non-custodial dispositions and of parole.

The subjects to be discussed at this conference indicate that the organisers have taken a cross-disciplinary approach. That is essential for any understanding of law and justice issues for they are generally expressions of particular aspects of the social matrix in which they arise. The conference includes a number of presentations under the heading 'Legal Practice' relating to the recruitment, retention and provision of public and private legal services and the use of technology to increase support for them. In the broader area of the legal service system, you will be considering Indigenous family violence, Indigenous mediation and the treatment and reintegration of criminal offenders. The problem of so-called naming and shaming summary offenders in a regional community is also under discussion. The large issues of environmental justice, water rights and sexual harassment are on your agenda. It is a full and diverse program. I congratulate the University on organising the conference and wish you well with it. 